\title{
The understory bat community in a fragmented landscape in the lowlands of the Los Tuxtlas, Veracruz, Mexico
}

\author{
Ismari Ramírez Lucho ${ }^{1}$, Rosamond Coates ${ }^{2}$ and Alvar González Christen ${ }^{3 *}$ \\ ${ }^{1}$ Programa de Pós-Graduação em Ecologia e Conservação/ CCBS. Universidade Federal de Mato Grosso do Sul. Cidade Universitária \\ s/n Bairro Universitário Campo Grande/MS, Brasil 79070-900. E. Email: selvaperennifolia@gmail.com (IRL), \\ ${ }^{2}$ Estación de Biología Tropical Los Tuxtlas, Instituto de Biología, Universidad Nacional Autónoma de México. Km. 32 Carretera \\ Catemaco-Montepío, CP. 95701, San Andrés Tuxtla. Veracruz, México. Email: rcoates@ib.unam.mx (RC). \\ ${ }^{3}$ Instituto de Investigaciones Biológicas Universidad Veracruzana. Av. Luís Castelazo s/n Col. Industrial Animas, CP. 91190, Xalapa. \\ Veracruz, México. Email: agonzalez@uv.mx (AGC). \\ * Corresponding author
}

Bat species in Neotropical regions are known to reach a high diversity. The Chiropteran fauna contributes significantly to the ecological dynamics of tropical forests and are excellent indicators of the state of conservation. The Los Tuxtlas, Veracruz has suffered severe habitat degradation and forest fragmentation in the last four decades, mostly due to anthropogenic activities. The main objective of the present study was to describe in terms of species richness, feeding guild, biomass, and dominance, the little known bat community of the Parque de Flora and Fauna Silvestre Tropical (PAFFASIT) in the municipality of Catemaco, Veracruz. We expected that after nearly 30 years of ambient protection that this study site would maintain its functional diversity, as well as complexity in the bat understory assemblage. Since the relationship between richness and abundance is regulated by area size and the structural complexity of the vegetation, we hypothesize that in the PAFFASIT, a small number of species in the understory are dominant in terms of abundance and biomass. Fieldwork was conducted from November 2007 to November 2008. Sixteen mist nets were operated on four consecutive nights monthly from dusk until 0300 hours. All bats captured were processed and released in the field. We estimate the overall species diversity. A species accumulation curve over time was constructed. All species were assigned a feeding guild. Sampling effort totaled 1344 net/hours. We captured a total of 509 individuals, which represented 22 species. The Phyllostomidae family accounted for $98 \%$ of the total captures. Four species of this family, Sturnira parvidens, Carollia sowelli, Artibeus jamaicensis and Glossophaga soricina, alone accounted for $79 \%$ of the total captures. The frugivore guild had the highest number of species (68\% of total captures). Two species, S. parvidens and C. sowelli, represented $57 \%$ of the total gross biomass of the sample. The ShannonWiener Index value was 1.97 for the overall sample. New species were added slowly each month, but after nine months the accumulation curve tended to reach an asymptote. Nine species were added to the bat inventory for this site. In PAFFASIT due to the slow accumulation of species the number of bat species may increase as more surveys are carried out. In our study, we initially hypothesized a dominance by a few species. Our results concur with our prediction; as we found four species, S. parvidens, C. sowelli, A. jamaicensis and G. soricina that dominated the bat assemblage. In agreement with our hypothesis, results revealed the presence of a rich understory assemblage of bat species, which is similar to other findings in neotropical forests, but with a different species composition. The four species, belonging to the Phyllostomidae family accounted for $79 \%$ of all captures, as well as $68 \%$ of the total captures of the frugivore guild. The PAFFASIT forest reserve probably serves as an important link between two large areas of relatively well-preserved rainforest immersed in an anthropogenic landscape. The bat community, we observed at the PAFFASIT seems to be a simplification of that of mature rainforests in Los Tuxtlas, and it is noteworthy the absence of rare or sensitive animalivorous bat species such a as Chrotopterus auritus, Lophostoma evotis, Trachops cirrhosus and Vampyrum spectrum.

Es elevada la diversidad de murciélagos en las regiones Neotropicales. La Chiropterofauna significativamente contribuye a la dinámica ecológica de los bosques tropicales y son excelentes indicadores de su estado de conservación. Durante las últimas cuatro décadas la región de Los Tuxtlas, veracruz ha sufrido una severa degradación del hábitat y fragmentación de sus bosques, principalmente por actividades antropogénicas. El objetivo de este estudio fue describir en términos de riqueza de especies, gremios alimenticios, biomasa y dominancia, la poco conocida comunidad de murciélagos del Parque de Flora and Fauna Silvestre Tropical (PAFFASIT) en el municipio de Catemaco, Veracruz. Esperamos que como resultado de los aproximadamente 30 años de protección ambiental en este sitio de estudio, el hábitat mantenga su diversidad funcional y también como una compleja comunidad de murciélagos del sotobosque. Como la relación entre la riqueza y abundancia de las especies es regulada por el tamaño del área y la complejidad estructural de la vegetación, hipótetizamos que, en el PAFFASIT, un pequeño número de especies dominan en términos de abundancia y/o Biomasa. Se realizó el trabajo de campo de noviembre de 2007 hasta noviembre de 2008, se utilizaron 16 redes de niebla, activadas mensualmente durante cuatro noches consecutivas desde el atardecer hasta las 0300. Todos los murciélagos fueron identificados y liberados en campo. Se estimo la diversidad de especies. Se elaboró una curva de acumulación de especies/tiempo. A cada especie se le asignó a un gremio alimenticio. El esfuerzo de muestreo fue de 1344 red/horas. Se capturaron 509 individuos que representan 22 especies. La familia Phyllostomidae aportó el $98 \%$ de las colectas. Cuatro especies de esta familia Sturnira parvidens, Carollia sowelli, Artibeus jamaicensis y Glossophaga soricina aportaron el $79 \%$ de las capturas. El gremio frugívoro tuvo el mayor número de especies ( $68 \%$ del total capturado). Dos especies, S. parvidens and C. sowelli representaron el $57 \%$ de la biomasa bruta. El valor del índice de Shannon-Wiener calculado fue 1.97. Mensualmente, se agregaron nuevas especies, pero después de nueve meses la curva de acumulación de especies tendió a alcanzar una asíntota. Se suman nueve especies al inventario de murciélagos conocido de este sitio. En el caso de los murciélagos, en PAFASSIT, debido a la lenta acumulación de especies, el número de especies puede incrementarse cuando se lleven a cabo más estudios. En nuestro estudio hipotetizamos una dominancia por pocas especies y coincidiendo con nuestra predicción encontramos que cuatro especies S. parvidens, C. sowelli, A. jamaicensis y G. soricina, dominan el ensamble de murciélagos. De acuerdo con nuestra hipótesis los resultados muestran también la presencia de un rico ensamble de murciélagos de sotobosque y son resultados similares a los obtenidos en otros estudios en bosques neotropicales, pero con diferente composición de especies. Observando la dominancia de cuatro especies (79 $\%$ de las colectas) de la familia Phyllostomidae y resaltando la importancia del gremio frugívoro. La vegetación del PAFFASIT actúa como una conexión importante entre dos grandes áreas de Selva tropical relativamente bien conservadas inmersas en un paisaje antropizado. La comu- 
nidad de murciélagos que observamos en PAFFASIT parece ser una simplificación de la de las selvas tropicales maduras de Los Tuxtlas, aunque es notoria la ausencia de especies carnívoras, raras o sensibles conocidas de Los Tuxtlas como Chrotopterus auritus, Lophostoma evotis, Trachops cirrhusus y Vampyrum spectrum.

Key words: Artibeus, biodiversity, Chiroptera, habitat fragmentation, Phyllostomidae, Sturnira, tropical rainforest.

๑ 2017 Asociación Mexicana de Mastozoología, www.mastozoologiamexicana.org

\section{INTRODUCTION}

The order Chiroptera is considered throughout the world as the second most diverse group of mammals at the species level only after the order Rodentia (Wilson and Reeder 2005). In Neotropical regions, bats are prominent components of mammalian communities and are known to place first with regard to species diversity (Gorresen and Willig 2004; Klingbeil and Willig 2010; Sánchez et al. 2012). Worldwide, more than 1300 extant species have been documented (Voigt and Kingston 2016), with 137 species documented in Mexico (Ramirez-Pulido et al. 2014). A relatively recent study involving the examination of Mexican specimens documented in the scientific collections within the country and abroad reports a diversity of 89 bat species for the state of Veracruz (González-Christen and Delfín-Alfonso 2016). Of these species more than half have been reported for the Los Tuxtlas region (Coates-Estrada and Estrada 1986; Martinez-Gallardo and Sanchez-Cordero 1997; GonzalezChristen 2008). Bats are important bioindicators of tropical ecosystem health, as they play a key role in the ecological dynamics of forests, especially in pollination, and promotion of seed dispersal throughout the primary and secondary vegetation. These services extend even to open spaces as well as pastureland (Fenton et al. 1992; Medellín et al. 2000; Castro-Luna et al. 2007; Melo et al. 2009; García-Estrada et al. 2012; Mass et al. 2013; Avila-Cabadilla et al. 2014; Voigt and Kingston 2016). Habitat loss and the resulting forest fragmentation are the major threats to Phyllostomid bats in the tropics. Bats are considered keystone species according to research on the effects of the forest fragmentation. However, fragmentation studies on tropical bats show contradictory results, and should be more widely investigated (Diogo 2015; Farneda et al. 2015; Meyer et al. 2016).

The original predominant vegetation of the lowland area in the Los Tuxtlas region was tall evergreen rainforest. In the last 50 years the forested areas of the region have been drastically altered and reduced due to human perturbation because of the expansion of agricultural activities and extensive cattle ranching practices. Today only between eigth and $10 \%$ of the original forest remains (Dirzo and Garcia 1992; Mendoza et al. 2005; Dirzo et al. 2009; Arroyo et al. 2009), and this presents a highly fragmented scenario consisting of pastureland, cultivations and varying stages of forest regeneration habitat. Studies on the effects of habitat fragmentation in the northwest portion of the Los Tuxtlas region on mammals, birds and plants are well documented (Estrada et al. 1993; Estrada and Coates-Estrada 2001a, Estrada and Coates-Estrada 2002; Galindo and Sosa 2003; Galindo 2004, Aguirre and Dirzo 2008; Arroyo et al. 2012). In the case of bats, studies in other areas have found that forest fragmentation tends to reduce the abundance of certain species and has an overall negative effect on species diversity (Medellín et al. 2000; Farneda et al. 2015; Muylaert et al. 2016).

In 1998, an area of 155,200 ha in the Los Tuxtlas region was decreed by the Mexican federal government as a Biosphere Reserve due to its high diversity of organisms and the northernmost location of the tropical rainforest on the American continent. The remaining extensive forest exists in three core areas (San Martín Tuxtla, San Martín Pajapan and Sierra Santa Martha) located at elevations over $800 \mathrm{~m}$. The size of the remaining forest fragments in the lowland areas $(0$ to $800 \mathrm{~m}$ ) varies from 1.0 to 700 ha (Estrada et al. 1993; Mendoza et al. 2005).

The aim of this study was to document the species richness, feeding guilds, biomass, and dominance of the understory species assemblage of bats in the Parque de Flora and Fauna Silvestre Tropical (hereafter PAFFASIT). This is a relatively little known area of the Los Tuxtlas region in the lowlands on the northeastern slope of the Sierra Santa Marta volcanic range. Due to the importance of bats in the maintenance of tropical forest natural regeneration and other key ecological processes such as pollination, insect predation, and seed dispersal, it is essential to document the presence of bat species in order to ascertain their roles and ecological impacts in the ecosystem, and to maintain the remaining biodiversity throughout the landscape as pointed out by Lim and Egstrom (2001). We expected that after nearly 30 years of environmental protection, this study site would have maintained its functional diversity, as well as complexity in the bat understory community. Since the relationship between richness and abundance is regulated by area size and the structural complexity of the vegetation, we hypothesize that in the PAFFASIT, a small number of species in the understory will be dominant in terms of abundance and biomass as has been found in other studies conducted on Neotropical bat assemblages.

\section{STUDY SITE AND METHODS}

Study site. Fieldwork was carried out in the PAFFASIT a 220 ha forest reserve situated northwest of Lake Catemaco, Veracruz, Mexico $18^{\circ} 26^{\prime}$ to $18^{\circ} 28^{\prime} \mathrm{N}$; $-95^{\circ} 01^{\prime}$ to $-95^{\circ} 03^{\prime} \mathrm{W}$, elevation 330 to $500 \mathrm{~m}$ (Figure 1). This protected area is owned and operated by the Universidad Veracruzana, which is the state university of Veracruz. The climate is warm and humid with an annual precipitation of $1,663 \mathrm{~mm}$. Annual temperatures range from a minimum of $18.3^{\circ} \mathrm{C}$ to a maximum of $25.1^{\circ} \mathrm{C}$ (Soto and Gama 1997). The vegetation within the reserve is high evergreen rainforest with dominant species such as Ficus yoponensis Desv, Poulsenia armata (Miq.) 


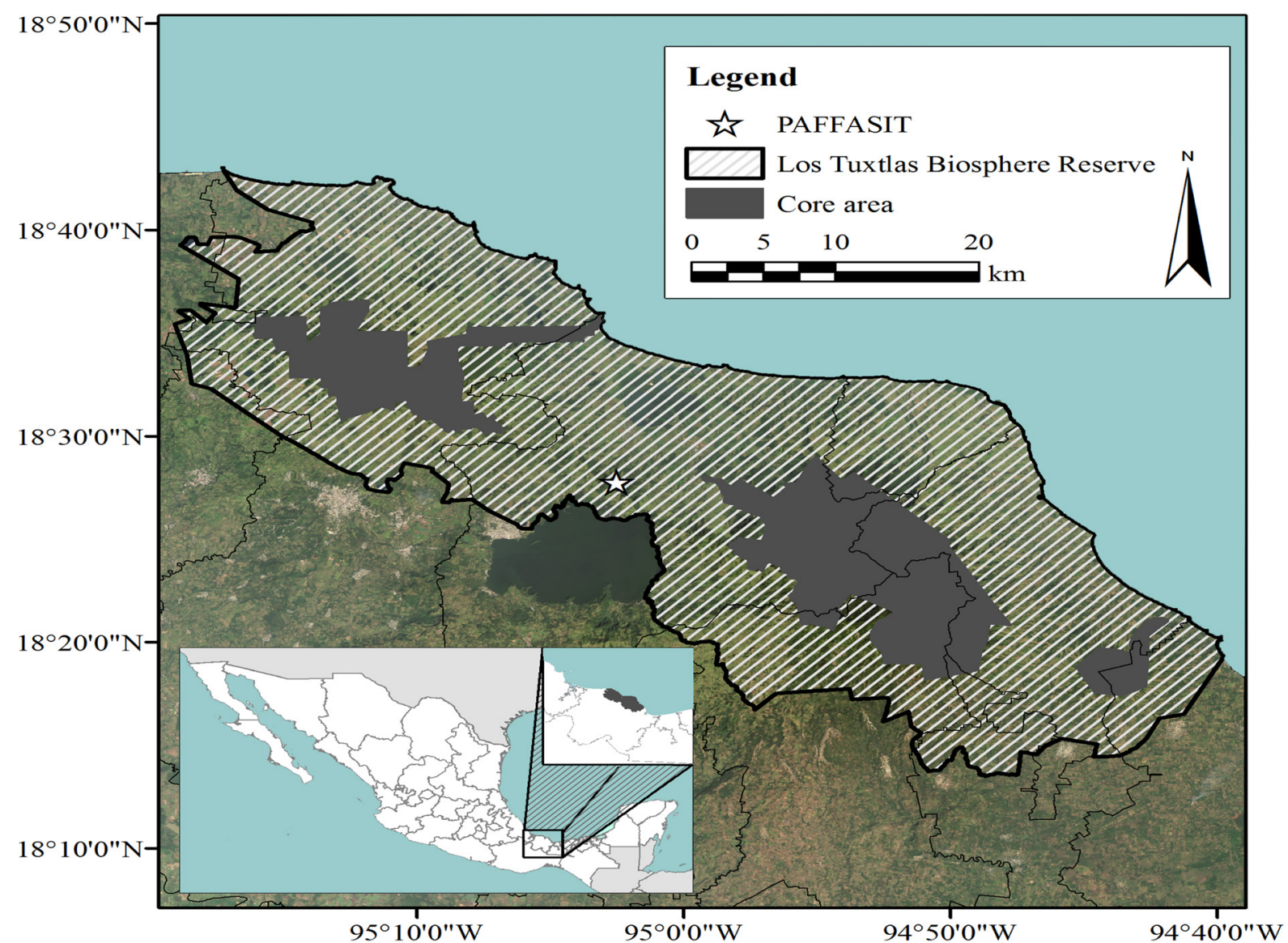

Figure 1 Map of the Study site location (PAFFASIT) within the Reserva de la Biosfera "Los Tuxtlas" where bats were captured. Latitude and longitude are shown on the vertical and horizontal axes respectively.

Standl, and Brosimum alicastrum Sw., mixed with species of medium height such as Guarea glabra Vahl, Garcinia intermedia (Pittier) B. Hammel, and Zanthoxylum kellermanii P. Wilson. However, the endemic bamboo (Olmeca recta Soderstrom), locally known as zongón, dominates certain areas. Many species of pioneer plants (Cecropia obtusifolia Bertol, Piper hispidum SW., and Solanum sp.) are found along the edges of the reserve and in the areas of natural perturbation within the site. Preliminary sampling of bats (Villa-Cañedo 1994) revealed the presence of 16 species.

We sampled the understory bat community by mist netting throughout the forest and at the edges of the adjoining pastureland of the PAFFASIT reserve monthly from November 2007 to November 2008. A total of 16 mist nets ( $6 \mathrm{~m}$ long $x 3 \mathrm{~m}$ height; $35 \mathrm{~mm}$ mesh) were placed at ground level along existing trails inside the vegetation but under the canopy. Each net was set approximately $50 \mathrm{~cm}$ above the ground and the maximum net height reached was $4 \mathrm{~m}$. We netted bats for two consecutive nights, twice each month. Nets were operated from dusk $(1,800$ to 2,000 hrs) until 0300 hours regardless of lunar phases. All bats caught were identified to species using a field identification key (Medellin et al. 1997, 2008). For each specimen we recorded weight, sex, reproductive state and certain taxonomically useful measurements were taken (total length, tail length, hind foot length, ear length, forearm length). All animals were released as soon as they were processed, and none were marked. Bats that perished due to bad weather, predators or that were unable to be identified in the field were preserved and prepared as voucher specimens and later deposited in the mammal collection of the Instituto de Investigaciones Biológicas of the Universidad Veracruzana in Xalapa, Veracruz. All animals captured were assigned to a feeding guild based on published dietary habits (Kalko et al. 1996, Segura-Trujillo et al. 2016). To determine the ecological impact of bats for this study site we used a measure of biomass (average weight in grams) for each species captured. Taxonomical nomenclature for the bats follows that used by Ramirez-Pulido et al. (2014).

Data analysis. For Species richness estimation, we used Chao 1 with abundance-based data and Chao2, Jackknives, and Bootstrap for incidence-based data (Coldwell 2016). To evaluate species richness, we used the Margalef index (Ludwig and Reynolds 1988). We used the Shannon-Wiener index in order to measure the overall species diversity within the community.

In order to evaluate the sampling effort over time we used a species accumulation curve (Magurran 2004). To calculate the gross biomass (GB) represented by each species we took an average of all recorded weights for the species captured and multiplied this by the total number of captures. 


\section{RESULTS}

The sampling effort of 1,344 total net/hours in this study captured 509 individuals. Of these, 267 (52\%) were males and 242 (48\%) were females. A total of 22 species (species richness) of bats were identified which represented 16 genera and three families. The most dominant family was that of the Phyllostomidae with a total number of 499 individuals captured (14 genera and 20 species respectively) and represented $98 \%$ of the total captures (Table 1). Four species, Carollia sowellii Baker, Solari and Hoffmann 2002, Sturnira parvidens Goldman 1917, Artibeus jamaicensis Leach 1821 and Glossophaga soricina Pallas 1766, accounted for $79 \%$ of all individuals captured. Sixteen species (70\%) were caught 10 times or less throughout the study.

The Shannon-Wiener index of 1.92 indicated relatively moderate species diversity for this study site and sampling effort. Nine species are reported as new additions to the PAFFASIT bat fauna, but are not new records for the region (Centurio senex Gray 1842; Chiroderma salvini Dobson 1878; Carollia perspicillata (Linnaeus 1758); Desmodus rotundus (É.Geoffroy Saint Hilaire 1810); Demanura watsoni (Thomas, 1901); Vampyressa thyone Thomas, 1909; Uroderma bilobatum Peters, 1866; Bauerus dubiaquercus Van Gelder, 1959 and Pteronotus davyi Gray, 1838.
When we consider gross biomass (GB), the top four most abundant species accounted for $76 \%$ of the total biomass (Figure 2). Of these, S. parvidens was the dominant species with regard to captures and alone accounted for $39 \%$ of the total biomass present. Nine other species accounted for less than $100 \mathrm{~g}$ each to the total biomass of the captures. Four distinct feeding guilds were established for the individuals captured (Kalko et al. 1996). Frugivores were represented by 16 species belonging to the Phyllostomidae, and this was the dominant feeding guild in terms of numbers of individuals captured (90\%), as well as for biomass estimates (93\%). The nectarivore guild accounted for six percent of the total species captures and three percent of the gross biomass (GB). Insectivores were poorly represented in the sampling and therefore accounted for only one percent of the total captures, but contributed to two percent of the gross biomass (GB). The remaining sanguinivore guild represented by $D$. rotundus contributed only three individuals to the total number of captures (Figure 2).

When we consider the accumulation curve of species captured over time and the richness estimators (abundance-based data) of species probably present in PAFFASIT indicated a range from 24 to 26 species diversity for this study site (Figure 3). Each month new species were slowly

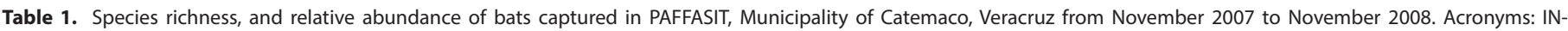
Insectivore; FR- Frugivore; N- Nectarivore; S- Sanguinivore. $\mathrm{n} / \mathrm{d}=$ no data, $\% \mathrm{~B}=$ Contribution of species to total Biomass; $\% \mathrm{C}=$ Percentage of captures.

\begin{tabular}{|c|c|c|c|c|c|c|c|c|}
\hline \multirow{3}{*}{ Family } & \multirow{3}{*}{ Species } & \multirow{3}{*}{$\begin{array}{l}\text { Feeding } \\
\text { Guild }\end{array}$} & \multicolumn{4}{|c|}{ Biomass (g) } & \multicolumn{2}{|c|}{ Captures } \\
\hline & & & \multicolumn{2}{|c|}{ Average } & \multirow{2}{*}{$\begin{array}{c}\text { by } \\
\text { species }\end{array}$} & \multirow{2}{*}{$\% \mathbf{B}$} & \multirow{2}{*}{$\begin{array}{c}\text { by } \\
\text { species }\end{array}$} & \multirow{2}{*}{$\% \mathrm{C}$} \\
\hline & & & female & male & & & & \\
\hline Mormoopidae & Pteronotus davyi fulvus (Thomas 1892) & IN & $\mathrm{n} / \mathrm{d}$ & 11 & 11 & 0.11 & 1 & 0.20 \\
\hline Mormoopidae & Pteronotus parnellii mexicanus Smith 1972 & IN & 23 & 24 & 91 & 0.88 & 6 & 1.18 \\
\hline Phyllostomidae & Carollia perspicillata azteca de Saussure 1860 & FR & 18 & 20 & 209 & 2.01 & 11 & 2.16 \\
\hline Phyllostomidae & Carollia sowelli Baker, Solari, and Hoffman 2002 & FR & 19 & 18 & 1,885 & 18.14 & 106 & 20.83 \\
\hline Phyllostomidae & Desmodus rotundus murinus J. A. Wagner 1840 & $\mathrm{~S}$ & 39 & 37 & 114 & 1.10 & 3 & 0.59 \\
\hline Phyllostomidae & Hylonycteris underwoodi underwoodi Thomas 1903 & $\mathrm{~N}$ & $\mathrm{n} / \mathrm{d}$ & 8 & 16 & 0.15 & 2 & 0.39 \\
\hline Phyllostomidae & Glossophaga soricina handleyi Webster and Jones 1980 & $\mathrm{~N}$ & 11 & 10 & 338 & 3.25 & 32 & 6.29 \\
\hline Phyllostomidae & Mimon cozumelae Goldman 1914 & $\mathrm{IN}$ & $\mathrm{n} / \mathrm{d}$ & 8 & 16 & 0.15 & 1 & 0.20 \\
\hline Phyllostomidae & Artibeus jamaicensis yucatanicus J. A. Allen 1904 & FR & 51 & 47 & 2,051 & 19.74 & 42 & 8.25 \\
\hline Phyllostomidae & Artibeus lituratus palmarum J. A. Allen and Chapman 1897 & FR & 57 & 63 & 582 & 5.60 & 10 & 1.96 \\
\hline Phyllostomidae & Dermanura phaeotis phaeotis Miller 1902 & FR & 14 & 14 & 271 & 2.61 & 19 & 3.73 \\
\hline Phyllostomidae & Dermanura tolteca tolteca (de Saussure 1860) & FR & 14 & 15 & 130 & 1.25 & 9 & 1.77 \\
\hline Phyllostomidae & Dermanura watsoni Thomas 1901 & FR & 17 & 15 & 120 & 1.15 & 9 & 1.77 \\
\hline Phyllostomidae & Centurio senex senex Gray 1842 & FR & $\mathrm{n} / \mathrm{d}$ & 24 & 24 & 0.23 & 1 & 0.20 \\
\hline Phyllostomidae & Chiroderma salvini Dobson 1878 & FR & 23 & $\mathrm{~s} / \mathrm{d}$ & 23 & 0.22 & 1 & 0.20 \\
\hline Phyllostomidae & Platyrrhinus helleri Peters 1866 & FR & $\mathrm{n} / \mathrm{d}$ & 20 & 79 & 0.76 & 4 & 0.79 \\
\hline Phyllostomidae & Uroderma convexum molaris Davis 1969 & FR & 16 & 18 & 141 & 1.36 & 8 & 1.57 \\
\hline Phyllostomidae & Vampyressa thyone Thomas. 1909 & FR & 12 & $\mathrm{~s} / \mathrm{d}$ & 12 & 0.12 & 1 & 0.20 \\
\hline Phyllostomidae & Vampyrodes major G. M. Allen 1909 & FR & 41 & 26 & 67 & 0.64 & 2 & 0.39 \\
\hline Phyllostomidae & Sturnira hondurensis hondurensis Goodwin. 1940 & FR & 25 & 20 & 346 & 3.33 & 16 & 3.14 \\
\hline Phyllostomidae & Sturnira parvidens Goldman 1917 & FR & 18 & 18 & 3,821 & 36.78 & 222 & 43.61 \\
\hline \multirow[t]{2}{*}{ Vespertilionidae } & Bauerus dubiaquercus Van Gelder 1959 & IN & 23 & 22 & 43 & 0.41 & 3 & 0.59 \\
\hline & Totals & & & & 10,390 & 100.00 & 509 & 100.00 \\
\hline
\end{tabular}


added to the sample and after nine months of sampling the number of species captured began to reach an asymptote, and no new species were added during the remaining months. The range of species expected went from 24 to 27 species. In Figure 2, we represent graphically the number of captures and the total biomass by species. The left skewedness of these data indicates that a large number of species captured were represented by only a very few individuals, most of them being frugivores. Figure 2 also demonstrated the same skewness when the data are arranged by feeding guilds.

\section{DISCUSSION}

Our study revealed, that even though there has been a severe transformation of habitat in the Los Tuxtlas region (Guevara et al. 2006), the presence of a rich understory assemblage of bat species persists on the PAFFASIT study site. From the data presented in the species accumulation curve (Figure 3), we feel confident that essentially all of the understory species present at this site were recorded. Perhaps there were species missed that were extremely rare or only occasional visitors, or species not vulnerable to capture by mist nets. Species such as Chrostopterus auritus (Peters 1856), Lophostoma evotis (W. B. Davis and Carter 1978), Trachops cirrhosus (Spix 1823) and Vampyrum spectrum (Linnaeus 1758), have only limited captures in other

\section{a) Captures}

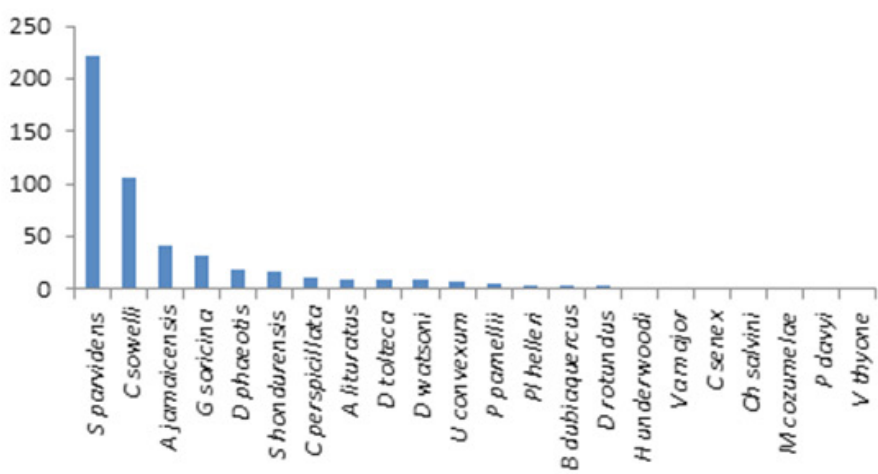

\section{c) Biomass}

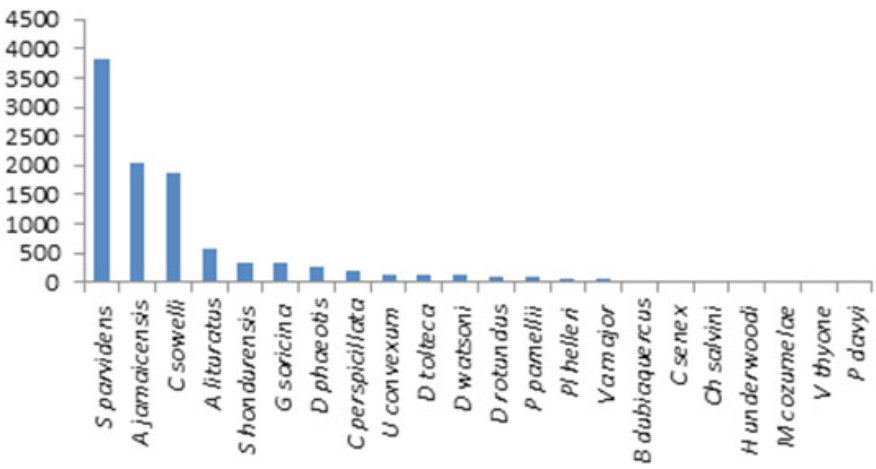

studies in the region (Estrada et al. 1993). Several other studies in the northwest portion of the Los Tuxtlas Biosphere reserve which involved more intensive and extensive sampling efforts reported bat assemblages of as many as 33 species captured in mist nets set in forest fragments of varying size (1.0 to 2000 ha; Estrada et al. 1993; Estrada and Coates-Estrada 2001a, $\underline{b} ; \underline{2002}$ ). On the other hand, the mammal beta diversity reaches high values in Los Tuxtlas. González-Christen (2008), registered 27 Phyllostomid species from 12 localities in the Sierra Santa Martha volcano range only a few kilometers away from PAFFASIT. However, only 16 of these species occurred within tall evergreen rainforest. All species reported for the PAFFASIT site have been documented in the areas surrounding the San Martín Tuxtla and Santa Martha volcanoes, with the exception of Bauerus dubiaquercus (Van Gelder 1959) and Vampyressa thyone not being recorded from the Sierra Santa Martha. It seems most likely that the PAFFASIT site serves as an important refuge and a connection between the faunas of two core areas (volcanoes San Martin Tuxtla and Santa Marta) as they are actually strongly isolated as a consequence of the recent habitat transformation that persists in the Los Tuxtlas (Dirzo and Garcia 1992; Mendoza et al. 2005; Dirzo et al. 2009; Arroyo et al. 2009). At the PAFFASIT site we recorded $34.4 \%$ of the bat species richness documented from Los Tuxtlas Biosphere Reserve.

\section{b) Captures}

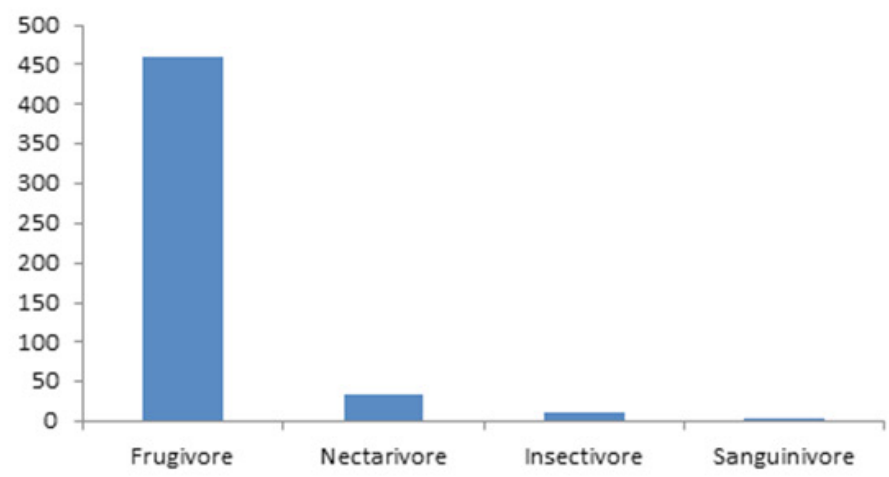

d) Biomass

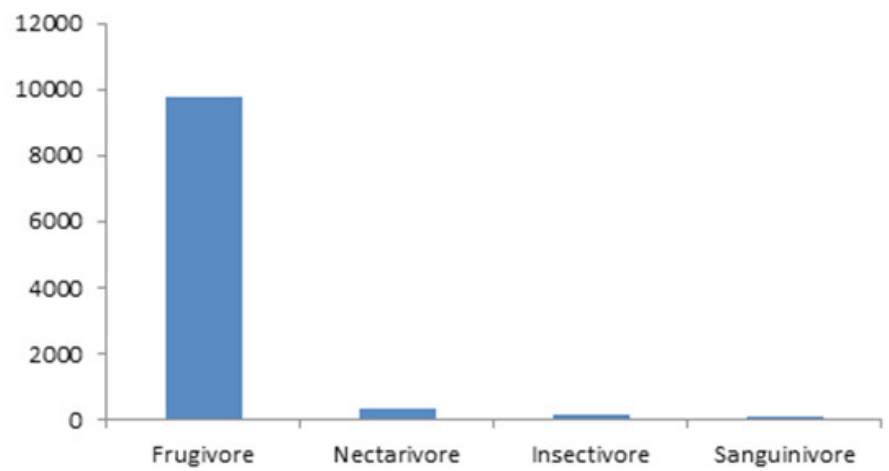

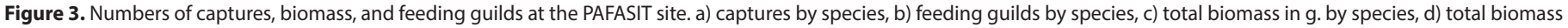
in g. by guilds. 
The bat community we observed at the PAFFASIT site seems to be a simplification of the original mature rainforests in Los Tuxtlas. Alternatively, the nine species reported in this study to be new to the local bat fauna may be due to a more intensive sampling effort over time at this locality. Still another possibility is that they may be an indicator of the responses of bats to the habitat fragmentation of the Los Tuxtlas landscape. We know that species use of various landscape elements depends on the spatial-temporal distribution of resources, connectivity, and configuration of structural landscape elements (Frey-Ehrenbold et al. 2013; Montaño et al. 2015). Either enhancement or decline in species richness can be anticipated. For example, a reduction of species richness was found by Avila-Cabadilla et al. (2009), De la Peña et al. (2012); Falcão (2014); Vleut et al. (2012, 2013). However, Bobrowiec and Gribel (2010) found similar bat richness in three types of secondary vegetation studied in Central Amazonia, but with different species composition in each vegetation type. A study in Amazonia by Klingbeil and Willig (2009) found a higher abundance and species richness in moderately fragmented forests

It is difficult to predict the effects of habitat fragmentation, especially in tropical areas. In our investigation, three species (Sturnira. parvidens, Carollia sowelli and Artibeus jamaicensis) accounted for $73 \%$ of all bats found at PAFFASIT. Similar studies in other tropical areas with anthropogenically modified landscapes, have also found these same species as the most abundant in the understory, probably due to the presence of preferred food resources such as Piper sp. or Solanum sp. (Griscon et al. 2007; Bolívar-Cimé et al. 2014; García-Estrada et al. 2012; Parolin et al. 2016).

In fragmented vegetation scenarios, bats move between the forest edges, mature forest, secondary growth, fruit plantations and grassland. Their response to landscape characteristics depends on the spatial scale, time, vegetation diversity, patch connectivity, and configuration (Medellín et al. 2000; Castro-Luna et al. 2007; Klingbeil and Willig 2010; Frey-Ehrenbold et al. 2013; Bolívar-Cimé et al. 2014; García-Estrada et al. 2012; Arroyo-Rodríguez et al. 2016; McGarigal et al. 2016; Meyer et al. 2016). Species respond distinctively at population, species, guild, and community levels with an array of mid and long-term strategies (AvilaCabadilla et al. 2012; García-Estrada et al. 2012). These are mediated by differential resource use or interspecific relationships (Cisneros et al. 2016) and changes in behavioral activity patterns (Montaño-Centellas et al. 2015). After 30 years of protection, the understory bat community of PAFFASIT has probably reached a steady state that is actually sustainable.

Some bats are more adaptable to human perturbations and may even flourish under such conditions, but others do not do well in disturbed vegetation. In fragmented habitats, this may explain the absence of species from higher trophic levels within the Phyllostomidae (Castro-Luna et al. 2007). This may be the case of Vampyrum spectrum, Chrostopterus auritus, Lophostoma evotis or Trachops cirrhosus which are

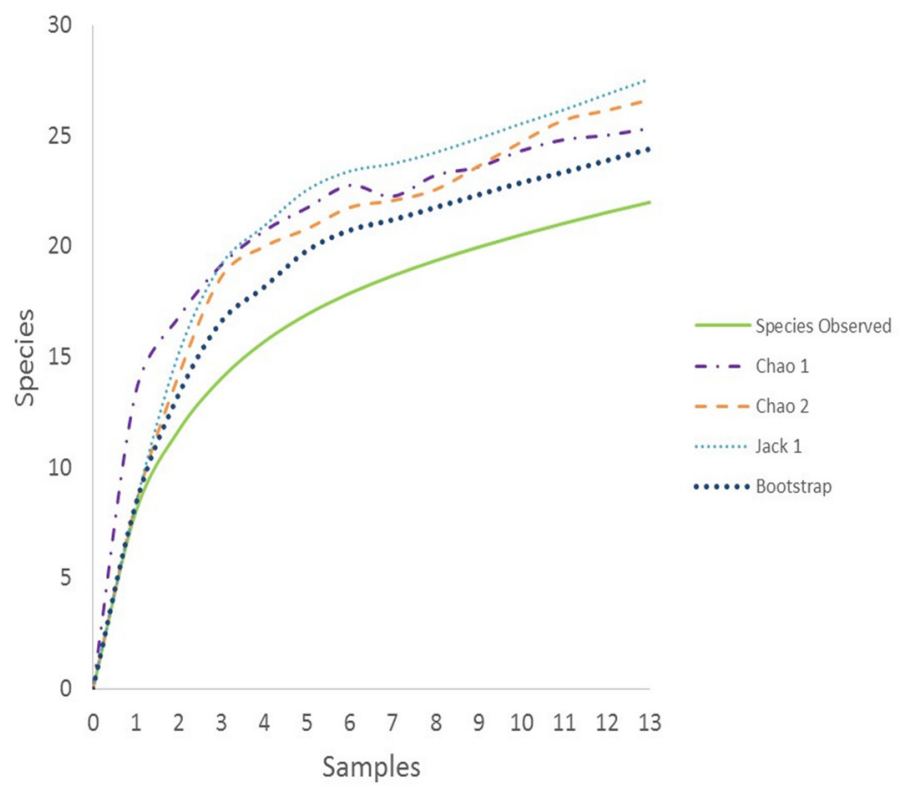

Figure 2. Bat species richness estimation. For abundance-based data we used Chao 1 , and for incidence-based data we used Chao2, Jackknives, and Bootstrap. Monthly samples from 1 = November 2007 until 13= November 2008.

reported scarce in the Los Tuxtlas region, but were absent at PAFFASIT. Farneda et al. (2015) pointed out that many "carnivorous" bat species rarely persist in small fragments $(<100$ ha). Although PAFFASIT is of moderate size, it is apparently not large enough to sustain these species. One possibility is that there is a deficiency of certain functional traits that are needed in order to fulfill the resource requirements of certain species, for example, the diversity of potential prey (Rocha et al. 2016). One other reason could be that the use of mist nets as the only sampling technique could be a limiting factor in the number of bat species documented at the PAFFASIT site.

The understory bat community we detected at our research site was basically composed of Phyllostomatid bats ( $68 \%$ of the 22 species documented), which probably were favored by the surrounding secondary vegetation. It remains uncertain, however, as to how much if any of this taxonomic bias has been modulated by the forest fragmentation in the surrounding areas. Similar results have been reported for rainforests and tropical dry forests in Mexico and Brazil (Avila-Cabadilla et al. 2009, 2014; Lim and Tavares 2012; De la Peña et al. 2012; Vleut et al. 2012, 2013; Muylaert et al. 2016).

\section{CONCLUSIONS}

We confirm the presence of 22 bat species in the understory of the PAFFASIT site. Four of these had especially high numbers of captures and accounted for the majority of all bats captured (Table 1). The most abundant feeding guild among this bat assemblage was frugivory (Table 1). All of the species captured have been previously documented in the Los Tuxtlas region, but the absence of bat species from higher trophic levels is evident. These findings support our hypothesis that the understory bat assemblage in this lowland tropical forest will be dominated by a small percent- 
age of the total bat species present, both in terms of numbers of captures and biomass (Figure 2a, b).

From a conservation perspective, the presence of an abundance of understory frugivorous bats is of great value for their role as seed dispersers not only within the PAFFASIT, but into the remaining mature forests in the region as well as throughout the surrounding anthropogenic landscape. The PAFFASIT also serves as an important connecting link or stepping stone for movements of the bat fauna between the two core protected forest areas of the Los Tuxtlas Biosphere reserve. Moreover, we want to emphasize the importance of the reserve for other conservation purposes at local and regional scales. We need to continue investigations on ecological aspects at PAFFASIT in order to determine which functional traits are fundamentally critical for maintaining the structure of the bat communities in this and other fragmented landscapes.

\section{ACKNOWLEDGEMENTS}

We wish to thank Francisco Orduña and the staff of PAFFASIT for authorizing and providing logistical support for our field research. We express our gratitude to William Lidicker Museum of Vertebrate Zoology. University of California. Berkeley, United States and two anonymous reviewers whose helpful comments and suggestions have improved this contribution.

\section{REFERENCES}

Aguirre, A., AND R. DiRzo. 2008. Effects of fragmentation on pollinator abundance and fruit set of an abundant understory palm in a Mexican tropical forest. Biological Conservation 14:375-384.

Arroyo-Rodríguez V., C. Jacob Dunn, J Benítez-Malvido, and S. Mandujano. 2009. Angiosperms, Los Tuxtlas Biosphere Reserve, Veracruz, Mexico. Check List, Campinas 5:787-799.

Arroyo-Rodríguez, V., M. Ros, F. Escobar, F. Melo, M. Tabarelli, AND B. SANTOS. 2012. Plant B-diversity in fragmented rain forests: testing floristic homogenization and differentiation hypotheses. Journal of Ecology 101:1449-1458.

Arroyo-Rodríguez, V., C. Rojas, R. A. Saldaña-Vázquez, and K. E. STONER. 2016. Landscape composition is more important than landscape configuration for phyllostomid bat assemblages in a fragmented biodiversity hotspot. Biological Conservation 198:84-92.

Avila-Cabadilla, L. D., K. E. Stoner, M. Henry, and M. Y. Alvarez-Añorve. 2009. Composition, structure and diversity of phyllostomid bat assemblages in different successional stages of a tropical dry forest. Forest Ecology and Management 258:986-996.

Avila-Cabadilla, L. D., G. A. Sanchez-Azofeifa, K. E. Stoner, M. Y. Alvarez-Añorve, M. Quesada, and C. A. Portillo-Quintero. 2012. Local and landscape factors determining occurrence of Phyllostomid bats in tropical secondary forests. PLoS ONE http://dx.doi.org/10.1371/journal.pone.0035228.

Avila-Cabadilla, L. D., K. E. Stoner, J. M. Nassar, M. M. Espírito-Santo, M. Y. Alvarez-Añorve, C. I. Aranguren, and G. A. Sanchez-Azofeifa. 2014. Phyllostomid bat occurrence in successional stages of
Neotropical dry forests. PLoS ONE http://doi.org/10.1371/ journal.pone.0084572.

Bolivar-Cimé, B. A, C, J. Laborde A, M. C. MacSwiney G. B, and V. J. SosA A. 2014. Effects of landscape matrix type, patch quality and seasonality on the diet of frugivorous bats in tropical semi-deciduous forest. Wildlife Research 41:454-464.

Bobrowiec, P. E. D., AND R. Gribel. 2010. Effects of different secondary vegetation types on bat community composition in Central Amazonia, Brazil. Animal Conservation 13:204216.

Castro-Luna, A. A., V. J. Sosa, and G. Castillo-Campos. 2007. Quantifying phyllostomid bats at different taxonomic levels as ecological indicators in a disturbed tropical forest. Acta Chiroptera 9:219-228.

Coates-Estrada, R., and A. Estrada. 1986. Manual de identificación de campo de los Mamíferos de la Estación de Biología "Los Tuxtlas". Universidad Nacional Autónoma de México. Ciudad de Mexico, México.

ColWELL, R. K. 2016. EstimateS: Statistical Estimation of Species Richness and Shared Species from Samples. Version 9.1.0. Published at http:// http://viceroy.eeb.uconn.edu/estimates/ index.htmls (21 Febrary 2017, date last accessed).

Cisneros, L. M., M. E. Fagan, And M. R. Willig. 2015. Season-specific and guild-specific effects of anthropogenic landscape modification on metacommunity structure of tropical bats. Journal of Animal Ecology 84:373-85.

De la Peña-Cuéllar, E, K. E. Stoner, L. D. Avila-Cabadilla, M. MartínezRamos, AND A. Estrada. 2012. Phyllostomid bat assemblages in different successional stages of tropical rain forest in Chiapas, Mexico. Biodiversity and Conservation 21:1381-1397.

DıoGo, F. A. F. 2015. Effects of seasonality on the responses of Neotropical bats to local- and landscape-scale attributes in a fragmented landscape. Mestrado em Biologia da Conservação. Universidade de Lisboa, Faculdade de Ciências, Departamento de Biologia Animal. Lisboa, Portugal.

Dirzo, R., A. Aguirre, AND J. C. López. 2009. Diversidad florística de las selvas húmedas en paisajes antropizados. Investigación Ambiental 1:17-22.

DiRzo, R., AND M. C. García. 1992. Rates of deforestation in Los Tuxtlas, a neotropical area in Southeast Mexico. Conservation Biology 6:84-90.

Falcão, L. A. D., do Espírito-Santo, M. M., Leite, L. O., Garro, R. N. S. L., Avila-Cabadilla, L. D., AND K. E. Stoner. 2014. Spatiotemporal variation in phyllostomid bat assemblages over a successional gradient in a tropical dry forest in southeastern Brazil. Journal of Tropical Ecology 30:123-132.

Estrada, A., And R. Coates-Estrada. 2001 a. Bat species richness in live fences and in corridors of residual rain forest vegetation at Los Tuxtlas, Mexico. Ecography 24:94-102.

Estrada, A., and R. Coates-Estrada. 2001b. Species composition and reproductive phenology of bats in a tropical landscape at Los Tuxtlas, Mexico. Journal of Tropical Ecology 17: 627646.

Estrada, A., and R. Coates-Estrada. 2002. Bats in continuous forest fragments and in an agricultural mosaic habitat-island at Los Tuxtlas, Mexico. Biological Conservation 103:237-245. Estrada, A., R. Coates-Estrada, AND D. MerRit, JR. 1993. Bat species richness and abundance in tropical rain forest fragments 
and in agricultural habitats at Los Tuxtlas México. Ecography 16:309-318.

Estrada-Villegas, S., J. Pérez-Torres, and P. Stevenson. 2007. Dispersión de semillas por murciélagos en un borde de bosque montano. Sociedad Venezolana de Ecología. Ecotropicos 20:1-14.

Farneda, F. Z., R. Rocha, A. López-Baucells, M. Groenenberg, I. Silva, J. M. Palmeirim, P. E. D. Bobrowiec, and C. F. J. MeYer. 2015. Traitrelated responses to habitat fragmentation in Amazonian bats. Journal of Applied Ecology 52:1381-1391.

Fenton, M. B., L. Acharya, D. Audet, M. B. C. Hickey, C. Merriam, M. K. ObRist, D. M. Syme, AND B. Adkins. 1992. Phyllostomid bats (Chiroptera: Phyllostomidae) as indicators of habitat disruption in the Neotropics. Biotropica 24:440-446.

Frey-Ehrenbold, A., F. Bontadina, R. ArlettaZ, and M. K. Obrist. 2013. Landscape connectivity, habitat structure and activity of bat guilds in farmland-dominated matrices. Journal of Applied Ecology 50:252-261.

Galindo-GonzÁlez, J. 2004. Clasificación de los murciélagos de Los Tuxtlas, Veracruz respecto a su respuesta la fragmentación del hábitat. Acta Zoológica Mexicana (n. s.) 20:239-243.

Galindo-González, J. S., S. S. Guevara, And V. J. Sosa. 2000. Bat-and bird-generated seed rains at insolated trees in pastures in a tropical rainforest. Conservation Biology 14:1693-1703.

Galindo-González, J., AND V. J. Sosa. 2003. Frugivorous bats in isolated trees and riparian vegetation associated with human-made pastures in a fragmented tropical landscape. The Southwestern Naturalist 48:579-589.

García-Estrada, C., Damon, A., Sánchez-Hernández, C., Soto-Pinto, L., ANd Ibarra-NúnezZ, G. 2012. Diets of Frugivorous Bats in Montane Rain Forest and Coffee Plantations in Southeastern Chiapas, Mexico. Biotropica 44:394-401.

GonZALEZ-ChRISTEN, A. 2008. La diversidad alfa, beta y gamma de la mastofauna de la Sierra de Santa Marta, Veracruz, México. Pp. 103-123, in Avances en el Estudio de los Mamíferos de México II. (Lorenzo, C., E. Espinoza, J., and Ortega, eds.). Publicaciones Especiales, Vol. Il Asociación Mexicana de Mastozoología, A. C., CIBNOR, ECOSUR, IPN, UAEM, UAM, UNICACH, Universidad Veracruzana. Ciudad de México, México.

González-Christen, A., and C. A. Delfin-Alfonso. 2016. Los mamíferos terrestres de Veracruz, México y su protección. Pp. 499-534 in Riqueza y Conservación de los Mamíferos en México a Nivel Estatal (Briones-Salas, M., Y. HortelanoMoncada, G. Magaña-Cota, G. Sánchez-Rojas, and J. E. Sosa-Escalante, eds.). Instituto de Biología, Universidad Nacional Autónoma de México, Asociación Mexicana de Mastozoología A. C. y Universidad de Guanajuato. Ciudad de México, México.

GorResen, P. M., AND M. R. WilLig. 2004. Landscape response of bats to habitat fragmentation in Atlantic Forest of Paraguay. Journal of Mammalogy 85:688-697.

Griscom, H. P., E. K. V. Kalko, And M. S. Ashton. 2007. Frugivory by small vertebrates within a deforested, dry tropical region of Central America Biotropica 39:278-282.

Guevara, S. S., J. Laborde, and G. SÁnchez-Ríos. 2006. La Fragmentación. In Los Tuxtlas. Pp 228, in El paisaje de la Sierra (Guevara S., J. Laborde, and G. Sánchez-Ríos. eds.). Instituto de Ecología, A. C. and Unión Europea. Ciudad de México, México.
Kalko, E. K. V., C. O. Handley, and D. Handley. 1996. Organization, diversity and long-term dynamics of a Neotropical bat community. Pp. 503-553, in Long term studies in vertebrate communities. (Cody, M., and J. Smallwood eds.). Academic Press. Los Angeles, U. S. A.

KLINGBELL, B. T., AND M. R. WILLIG. 2009. Guild-specific responses of bats to landscape composition and configuration in fragmented Amazonian rainforest. Journal of Applied Ecology 46:203-213.

KLINGBELL, B. T., AND M. R. WiLLIG. 2010. Seasonal differences in population-, ensemble- and community-level responses of bats to landscape structure in Amazonia. Oikos 119:16541664.

LIM, B.K., AND ENGSTROM, M.D. 2001. Bat community structure at Iwokrama Forest, Guyana. Journal of Tropical Ecology 17: 647-665.

LIM, B. K., AND V. DA C. TAVARES. 2012. Review of species richness and biogeography of bats (Chiroptera) from the Guiana subregion of South America with comments on conservation. Ecotropica 18:105-118.

LUDWIG, J. A., AND J. F. REYNOLDS. 1988. Statistical ecology: a primer on methods and computing. Wiley Interscience Publication J. Wiley \& Sons, Inc. New York, U. S. A.

MagurRan, A. E. 2004. Measuring biological diversity. Blackwell Science Ltd. Cornwall, United Kingdom.

Martinez-Gallardo, R., and V. Sanchez-Cordero. 1997. Lista de mamíferos terrestres. Pp. 625-628, in Historia Natural de Los Tuxtlas. (González Soriano, E., R. Dirzo and R. C. Vogt eds.). Instituto de Biología, UNAM, CONABIO e Instituto de Ecología, UNAM. Ciudad de México, México.

MaAs, B. Y., Clough, and T. Tscharntke. 2013. Bats and birds increase crop yield in tropical agroforestry landscapes. Ecology Letters 16:1480-1487.

Mcgarigal, K., H. Y. Wan, K. A. B. Zeller, C. Timm, and S. A. Cushman. 2016. Multi-scale habitat selection modeling: a review and Outlook Landscape Ecology 31:1161-1175.

Medellín, R. A., H. T. Arita, And O. H. Sanchez. 1997. Identificación de los Murciélagos de México. Publicaciones especiales No 2. Asociación Mexicana de Mastozoología, A. C. Ciudad de México, México.

Medellín, R. A., H.T. Arita, AND O. H. SAnchez. 2008. Identificación de los Murciélagos de México. Instituto de Ecología Universidad Nacional Autónoma de México. Ciudad de México, México. Medellín, A., Equinua, M., And Amin M. 2000. Bat diversity and abundance as indicators of disturbance in Neotropical forest. Conservation Biology 14:1666-1675.

Melo, F. P. L, B. Rodriguez-Herrera, R. L. Chazdon, R. A. Medellin, AND G. G. Ceballos. 2009. Small tent-roosting bats promote dispersal of large-seeded plants in a Neotropical forest. Biotropica 41:737-743.

Mendoza, E. J., J. Fay and R. Dirzo. 2005. A quantitative study of forest fragmentation in a neotropical area in southeast Mexico. Revista Chilena de Historia Natural 78:451-467.

Meyer, C. F. J., M. J. Struebig, AND M. R. Willig. 2016. Responses of Tropical Bats to Habitat Fragmentation, Logging, and Deforestation Pp. 63-103 in Bats in the Anthropocene: Conservation of Bats in a Changing World (Voigt, C. C., and T. Kingston eds). Ebook. Springer International Publishing. London, United Kingdom. 
Montaño-Centellas, F., M. I. M., L. F. Aguirre, R. Galeon, O. Palabrala, R. Hurtado, I. Galarza, and J. Tordoya. 2015. Community and species-level responses of phyllostomid bats to a disturbance gradient in the tropical Andes. Acta Oecologica 62:10-17.

Muylaert, R. L., R. D. Stevens, and M. C. Ribeiro. 2016. Threshold effect of habitat loss on bat richness in cerrado-forest landscapes. Ecological Applications 26:1854-1867.

Ramírez-Pulido, J., N. González-Ruiz, A. L. Gardner, and J. ArroyoCABRAles. 2014. List of recent land mammals of Mexico. Special Publications of the Museum of Texas Tech University 63:1- 69.

Parolin, L. C., B. Gledson v., and M. Sandra B. 2016. Consistency in fruit preferences across the geographical range of the frugivorous bats Artibeus, Carollia and Sturnira (Chiroptera). Iheringia, Série Zoologia 106: e2016010.

Rocha, R., A López-Baucells, F. Z. Farneda, M Groenenberg, P. E. D. Bobrowiec, M Cabeza, J. M. Palmeirim, and Chr. F. J. Meyer. 2016. Consequences of a large-scale fragmentation experiment for Neotropical bats: disentangling the relative importance of local and landscape-scale effects. Landscape Ecology DOI 10.1007/s10980-016-0425-3.

SÁncheZ M. S., N.P. Gianninia, And R. M. BarqueZa. 2012. Bat frugivory in two subtropical rain forests of Northern Argentina: Testing hypotheses of fruit selection in the Neotropics. Mammalian Biology 77:22-31.

Segura-Trujillo, C., W. Z. Lidicker, Jr., and S. T. Alvarez-Castañeda, 2016. New perspectives on trophic guilds of arthopodivorous bats in North and Central America. Journal of Mammalogy 97:644-654.

Soto, M., AND L. Gama. 1997. Climas. Pp. 7-23, in Historia Natural de los Tuxtlas (González Soriano E, R., Dirzo, and C. Vogt, eds.). Universidad Nacional Autónoma de México. Ciudad de México, México.

Villa-Cañedo, J. T. 1994. "Los Mamíferos del Parque de Flora y Fauna Silvestre Tropical (Mpio. De Catemaco, Veracruz, México): Inventario y alternativas para su conservación". Tesis de Licenciatura. Universidad Veracruzana. Xalapa, México.

Vleut, I., S. I. Levy-Tacher, J. Galindo-González, W. F. de Boer, and N. Ramírez-Marcial. 2012. Tropical rain forest matrix quality affects bat assemblage structure in secondary forest patches. Journal of Mammalogy 93:1469-1479.

Vleut, I., S. I. LeVy-TACher, W. F. de Boer, J. Galindo-González, And L. B. VAzQuez. 2013. Tropical Secondary Forest Management Influences Frugivorous Bat Composition, Abundance and Fruit Consumption in Chiapas, Mexico. PLoS ONE 8(10): e77584.

Voigt, C. C., And T. Kingston. 2016. Bats in the Anthropocene. Pp. 1-9, in Bats in the Anthropocene: Conservation of Bats in a Changing World (Voigt, C. C., and T. Kingston eds.). Springer Cham Heidelberg, New York, Dordrecht, London.

Wilson, Don E., And D. A. M. Reeder (eds). 2005. Mammal Species of the World. A Taxonomic and Geographic Reference (3rd ed.). Johns Hopkins University Press. Baltimore, U. S. A.

Associated editor: Williams Lidicker

Submitted: November 9, 2016; Reviewed: November 21, 2016;

Accepted: February 23, 2017; Published on line: March 15, 2017. 
